\title{
PIONEER PHOTOGRAPHERS
}

\author{
FROM THE \\ MISSISSIPPI \\ TO THE \\ CONTINENTAL DIVIDE
}




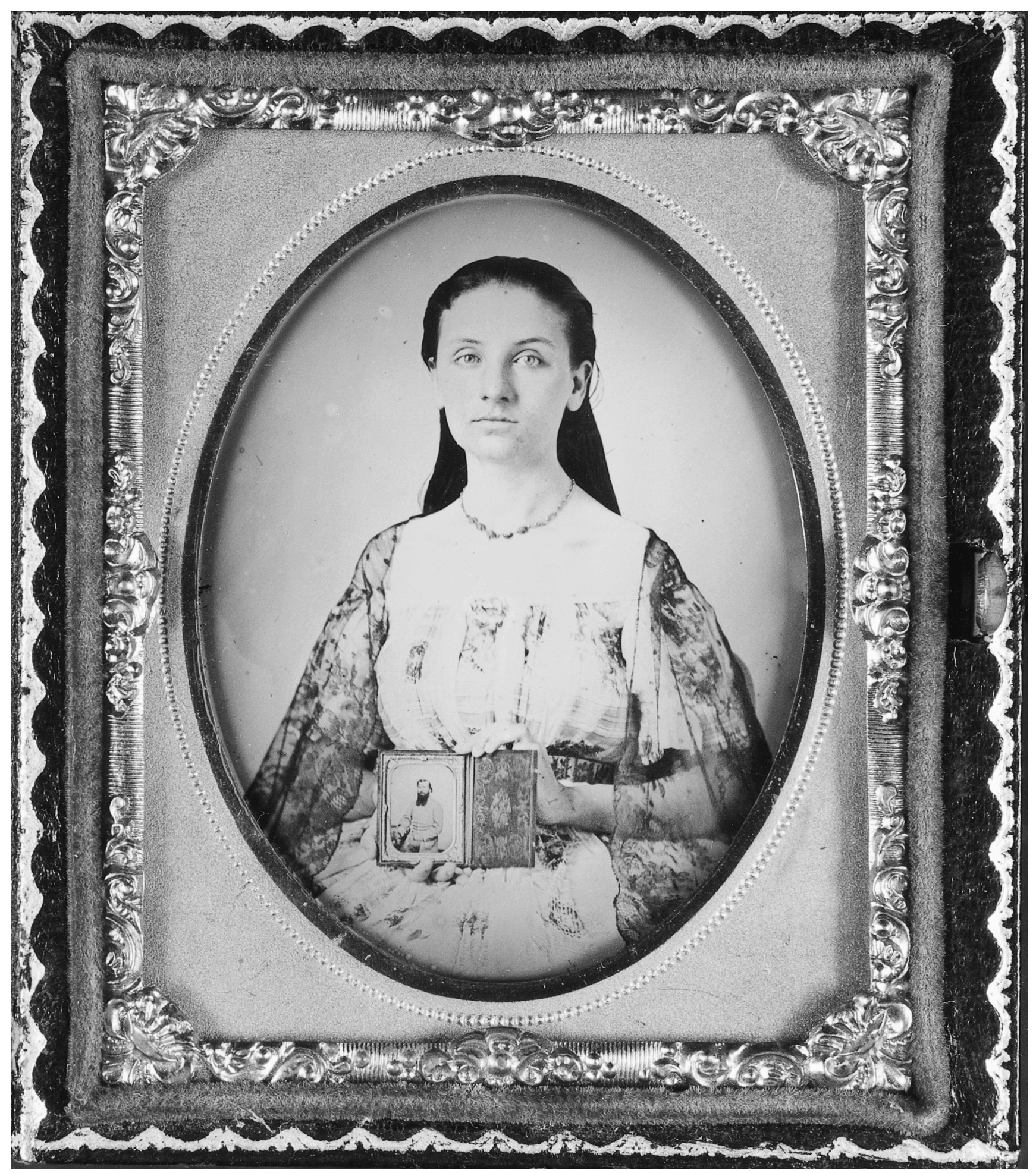

FIG. 1. Josephine "Josie" Scott, wife of Captain John G. Scott, 1st Texas Infantry Regiment. Ninth-plate ambrotype by Isaac Cline, Palestine, Texas, July 1863. (Lawrence T. Jones, III) 


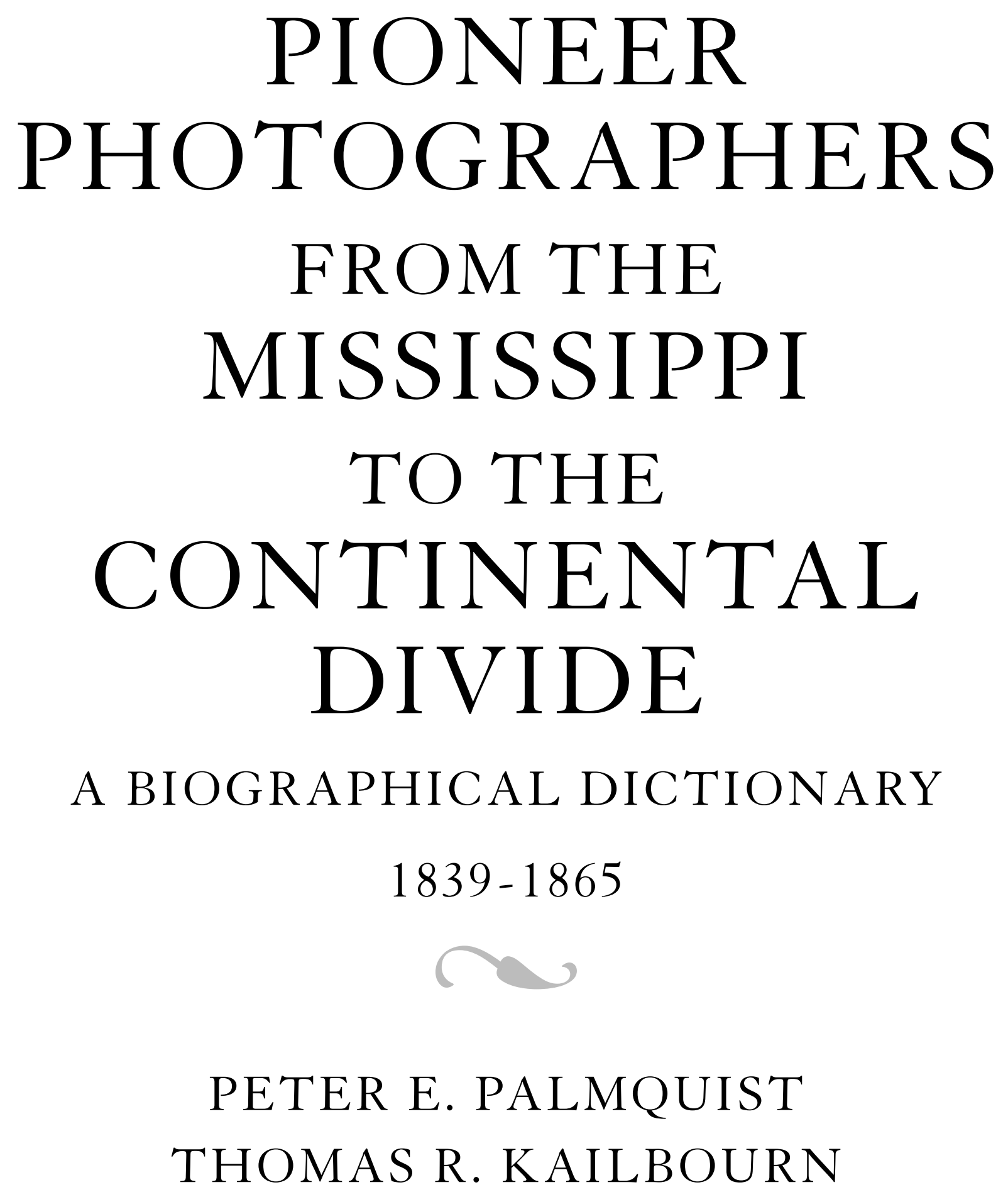

Stanford University Press

Stanford, California 


\author{
Stanford University Press \\ Stanford, California \\ C) 2005 by the Board of Trustees \\ of the Leland Stanford Junior University \\ Printed in the United States of America
}

Published with the assistance of the Leon E. Seltzer Memorial Book Fund.

Library of Congress Cataloging-in-Publication Data

Palmquist, Peter E.

Pioneer photographers from the Mississippi to the continental divide : a biographical dictionary, 1839-1865 / Peter E. Palmquist, Thomas R.

Kailbourn.

p. $\mathrm{cm}$.

Includes bibliographic references.

ISBN 978-0-8047-4057-9 (cloth : alk. paper)

1. Photographers-West (U.S.) — Biography_Dictionaries.

2. Photography - West (U.S.) - History - 19th century.

3. West (U.S.) - Biography-Dictionaries.

I. Kailbourn, Thomas R. II. Title.

TR139.P345 2005

770'.92'279—dc22

2004019262

This book printed on acid-free, archival-quality paper.

Original Printing 2005

Last figure below indicates year of this printing:

$\begin{array}{llllllllll}14 & 13 & 12 & 11 & 10 & 09 & 08 & 07 & 06 & 05\end{array}$

Typeset by BookMatters in Granjon. 
In appreciation to my brothers:

John Frederick Palmquist and Carl Edward Palmquist

P.E.P.

For Roxane Reid Schmidt, with love T.R.K. 
